\title{
Factors associated with subclinical atherosclerosis in HIV infected patients from
}

\section{northeast of Brazil}

Fatores associados à aterosclerose subclínica em pacientes infectados pelo HIV no nordeste do

\section{Brasil}

Factores associados com la aterosclerosis subclínica em pacientes infectados por el VIH del noreste

de Brasil

Received: 09/11/2021 | Reviewed: 09/19/2021 | Accept: 09/24/2021| Published: 09/26/2021

Ursula Maria Moreira Costa Burgos

ORCID: https://orcid.org/0000-0001-7234-4046

Federal University of Sergipe, Brazil Tiradentes University, Brazil

E-mail: ursulacostab@gmail.com

Enaldo Vieira de Melo

ORCID: https://orcid.org/0000-0002-9314-4331 Federal University of Sergipe, Brazil

E-mail: evmsidarta@gmail.com

Angela Maria da Silva

ORCID: https://orcid.org/0000-0001-9330-537X

Federal University of Sergipe, Brazil

E-mail: angela.silva910@gmail.com

Antônio Carlos Sobral Sousa

ORCID: https://orcid.org/0000-0003-0439-9808

Federal University of Sergipe, Brazil

E-mail: acssousa@ terra.com.br

Willams de Matos

ORCID: https://orcid.org/0000-0001-7724-1978

Federal University of Sergipe, Brazil

E-mal: willamsdematos@yahoo.com.br

Maria Aline Moura Reis

ORCID: https://orcid.org/0000-0002-1256-6824

Tiradentes University, Brazil

E-mail: alineemou@hotmail.com

Lucas Alves Bezerra

ORCID: https://orcid.org/0000-0002-2512-0573

Tiradentes University, Brazil

E-mail: luckasbezerra@gmail.com

Dalmo Correia Filho

ORCID: https://orcid.org/0000-0002-2174-5058

Federal University of the Triângulo Mineiro, Brazil

E-mail: dalmo@mednet.com.br

Joselina Luzia Menezes Oliveira

ORCID: https://orcid.org/0000-0002-4325-0590

Federal University of Sergipe, Brazil

E-mail: joselinamenezes@gmail.com

\begin{abstract}
Introduction: AIDS has changed its morbidity curve, rising cardiovascular diseases. HIV-infected patients have increased cardiovascular event rates but data on the prevalence of subclinical atherosclerosis are not uniform. Methods: HIV-infected patients underwent to coronary tomography for CACs assessement. We performed a comparison between $97 \mathrm{HIV}$-infected patients and 129 seronegative healthy controls. The univariable analysis matched the association of HIV infection, cardiovascular risk profile, and HIV-related factors with subclinical

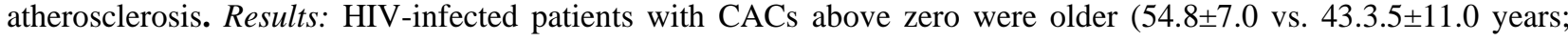
$\mathrm{p}<0.001)$ and more likely to have hypertension $(36.7 \%$ vs. $12.5 \%$; $=0.07)$ than HIV(-) CACs zero ones. Factors associated with altered CACs in unadjusted hazard ratio were age $(\mathrm{HR}=1.13 ; 95 \% \mathrm{CI}=1.07-1.20 ; \mathrm{p}<0.0001)$ and hypertension $(\mathrm{HR}=4.05 ; 95 \% \mathrm{CI}=1.42-11.60 ; \mathrm{p}=0.0009)$. When adjusted hazard ratio was constructed age, male gender and protease inhibitors (PI) use appeared as factors associated with coronary calcification. HIV-infected patients were less likely to have hypertension $(20.2 \%$ vs $50.4 \%$; $<0.001)$ and diabetes $(5.3 \%$ vs $23.3 \%$; $<<0.001)$
\end{abstract}


than HIV uninfected ones. Conversely, both groups have same CACs level. Among HIV-infected patients altered CACs was $30.9 \%$, vs $42.3 \%$ among control. Most of HIV-infected patients showed undetectable viremia and high CD4+ count, in parallel with lipid profile disturbances. Conclusion: Increased CAC incidence was associated with age, male gender and PI use among HIV-infected patients. Despite younger, fewer traditional risk factors and with controlled disease, the PLHIV had similar CAC scores compared with controls. Besides viruses itself, antiretroviral drugs play a role, mainly because control viruses at expense of worsening in lipid profile.

Keywords: HIV; AIDS; Cardiovascular risk factors; Coronary calcium score; Coronary calcification.

\title{
Resumo
}

Introdução: A AIDS mudou sua curva de morbidade, aumentando as doenças cardiovasculares. Pacientes infectados pelo HIV têm taxas aumentadas de eventos cardiovasculares, mas os dados sobre a prevalência de aterosclerose subclínica não são uniformes. Métodos: Pacientes infectados pelo HIV foram submetidos à tomografia coronariana para avaliação do EC. Realizou-se um comparação entre 97 pacientes infectados pelo HIV e 129 controles saudáveis soronegativos. Resultados: Pacientes infectados pelo HIV com EC acima de zero eram mais velhos (54,8 \pm 7,0 vs. 43,3,5 $\pm 11,0$ anos) e mais propensos a ter hipertensão (36,7\% vs. 12,5\%) do que os HIV(-) com EC zero. Os fatores associados a EC alterado na razão de risco não ajustada foram idade $(H R=1,13$; IC 95\% =1,07-1,20) e hipertensão $(\mathrm{HR}=4,05$; IC 95\% = 1,42-11,60). Quando a razão de risco ajustada foi construída, o sexo masculino e o uso de inibidores de protease (IP) apareceram como fatores associados à calcificação coronariana. Pacientes infectados pelo HIV eram menos propensos a ter hipertensão ( $20,2 \%$ vs $50,4 \%$; p <0,001) e diabetes $(5,3 \%$ vs $23,3 \%)$ do que os não infectados pelo HIV. Conclusão: O aumento da incidência de EC foi associado à idade, sexo masculino e uso de IP entre pacientes infectados pelo HIV. Apesar de mais jovens, menos fatores de risco tradicionais e doenças controladas, as PVHIV tiveram níveis de EC semelhantes em comparação com os controles. Além do próprio vírus, os antirretrovirais desempenham um papel importante, porque controlam os vírus às custas da piora do perfil lipídico.

Palavras-chave: HIV; AIDS; Fatores de risco cardiovasculares; Escore de cálcio coronariano; Calcificação coronariana.

\begin{abstract}
Resumen
Introducción: El SIDA ha cambiado su curva de morbilidad, aumentando la enfermedad cardiovascular. Los pacientes infectados por el VIH tienen mayores tasas de eventos cardiovasculares, pero los datos sobre la prevalencia de la aterosclerosis subclínica no son uniformes. Métodos: A los pacientes infectados por el VIH se les realizó una tomografía coronaria para evaluar el SC. Se realizó una comparación entre 97 pacientes infectados por el VIH y 129 controles sanos seronegativos. Resultados: los pacientes infectados por el VIH con CE por encima de cero eran mayores $(54,8 \pm 7,0$ frente a 43,3,5 $\pm 11,0$ años) y más propensos a tener hipertensión $(36,7 \%$ frente a $12,5 \%)$ que el VIH (-) sin CE. Los factores asociados con la CE alterada en el índice de riesgo no ajustado fueron la edad (HR = 1,13; IC del 95\% = 1,07-1,20) y la hipertensión ( HR = 4,05; IC del 95\% = 1,42-11,60). Cuando se construyó la razón de riesgo ajustada, el sexo masculino y el uso de inhibidores de la proteasa (IP) aparecieron como factores asociados con la calcificación coronaria. Los pacientes infectados por el VIH tenían menos probabilidades de tener hipertensión $(20,2 \%$ frente a $50,4 \% ; \mathrm{p}<0,001)$ y diabetes $(5,3 \%$ frente a $23,3 \%)$ que los que no estaban infectados por el VIH. Conclusión: La mayor incidencia de EC se asoció con la edad, el sexo masculino y el uso de IP entre los pacientes infectados por el VIH. A pesar de ser más jóvenes, factores de riesgo menos tradicionales y enfermedades controladas, las PVVIH tenían niveles de CE similares en comparación con los controles. Además del virus en sí, los antirretrovirales juegan un papel importante, ya que controlan los virus a expensas de empeorar el perfil lipídico.
\end{abstract}

Palabras clave: VIH; SIDA; Factores de riesgo cardiovascular; Score de calcio coronario; Calcificación coronaria.

\section{Introduction}

Approximately 37 million people live with human immunodeficiency virus (HIV) in the world, which is an important public health problem (WHO, 2016). Antiretroviral therapy (ART) era, especially protease inhibitors (PI) has changed HIV infection course into a medically controllable chronic disease with non-acquired immunodeficiency syndrome (AIDS) related illnesses taking place (Ingle SM et al, 2014). Non-communicable diseases such as coronary artery disease (CAD) raised in this population, changing morbity and mortality cause profile (WHO, 2016; Ingle SM et al, 2014; Chandra et al, 2019). A higher life expectancy resulting from better access to ART allows particularly coronary artery disease (CAD), which have been challenging. A higher prevalence of CAD was found, due to complex interactions among chronic HIV infection, antiretroviral therapy and individual factors (Lang S et al, 2015; Senoner T et al, 2019). Researches have focused attention on the potential role of HIV infection and its treatments in the pathogenesis of CAD among treated HIV-infected persons, although specific mechanisms leading to these increased risks are not well described (Lewden et al, 2007; Triant et al, 2007). Coronary artery 
calcium (CAC) has repeatedly been shown to be highly predictive of future coronary events in the general population and then used it is used to study CAD among HIV-infected patients (Freiberg et alt, 2013; Sara L et al, 2014). Seropositive patients have an elevated CAC incidence in comparison with seronegative individuals (Erbel R et al, 2010). Traditional risk scores, such as Framingham Risk Score, usually underestimate HIV-infected patients risk (Kingsley L et al, 2015). Recent data have been used to generate a cardiovascular (CV) risk model for HIV-infected patients using traditional risk factors in addition to HIV-specific risk factors such as CD4+ count and exposure to protease inhibitors, however this markers and other similar ones have not been validated (Mooney S et al, 2015). Coronary Artery Calcium Score (CACs) is an independent risk predictor in general population, able to redefine risk, mainly those with intermediate risk on clinic scores (Sara L et al, 2014)). Incorporating CACs to estimate HIV-infected patients CV risk could be a chance for better management and prevention strategies use ( Erbel R et al, 2010). In addition, a local research is also welcome because unfortunately, unlike Europe and United States, in developing countries researches in this area are scant (Friis-Møller N et al, 2016). Indeed, Northeast Brazil HIV-infected patients experience a lot of distress to have treatment access as a neglected condition (Juliu H et al, 2011). Find what factors are associated with CAC in asymptomatic HIV-infected patients treated with ART will help to plan prevention strategies. In addition, a local research is also welcome because, unlike Europe and United States, in developing countries HIV/AIDS researches specifically on CAC are relatively scant (Kingsley L et al, 2015). Determining CACs in asymptomatic HIV-infected patients treated with ART in comparison with asymptomatic seronegative patients can reveal important clues to better prevention strategies.

\section{Methodology}

\subsection{Study cohort}

This is a transversal observational study enrolling 97 HIV-infected patients from October 2017 to November 2018, excluding symptomatic patients as well as those with established CAD, opportunistic infections clinical signs, recent hospitalization, or pregnant. A control group of asymptomatic HIV-negative healthy individuals was recruited to comparison. They came from a CT data bank of individuals without documented CAD who had CT scans for clinical purposes in the same site during the above period. The study was approved by the institutional ethics committee under protocol number 2.244.171.

\subsection{Data collection, risk factor classification, and outcomes}

Patients were tested for HIV antibodies by using serologic testing (ELISA). CD4+ count and viremia were determined. Lipid profile and blood glucose were measured from fasting blood. Study authors collected demographic information, HIV/AIDS long term and traditional risk factors during initial visit (information about hypertension, dyslipidemia and diabetes were self-declared by the patients in response to our questionnaire; smoking was considering everyone who actually smokes any tobacco product, either daily or occasionally). A central pharmaceutics provided information about all ART regimens and time of use. We performed non-contrast cardiac CT studies using multi-detector row CT scanners (64MDCT). Our scanners used intensity-based threshold at $130 \mathrm{HU}$. The imaging protocol adhered to the Society of Cardiovascular Computed Tomography guidelines on appropriateness and performance of CCTA. Patient preparation, data acquisition, and analysis were according to the institutional policies of the local site. Toshiba (Aquilion64 ${ }^{\mathrm{TM}}-$ Toshiba $^{\mathrm{TM}}$ Medical Systems Corporation, Otawa, Japão) and Siemens (Somaton Definitivos $A S^{\mathrm{TM}}$ - Siemens ${ }^{\mathrm{TM}}$ Healthcare, Erlangen, Alemanha) were machines used for cases and controls. CAC scores computed using the Agatston calculator (Almeida-Brasil C et al, 2019) and a positive CAC was defined as Agatston score different from zero. 


\subsection{Statistical analyses}

Comparison between HIV infected (HIV+) and HIV uninfected (HIV-) patients was reached in univariate analyses with $\mathrm{p}$ less than 0.05 considered significant. Results were expressed as absolute or relative frequencies, mean and standard deviation. All analyses were performed in SPSS/PC 23.0 Software.

\section{Results}

3.1 Comparison by presence or absence of CAC in HIV-infected patients

Table 1. Comparison between HIV-infected patients by presence or absence of CAC.

\begin{tabular}{llll}
\hline & Without CAC (n=66) & With CAC $(\mathrm{n}=31)$ & p \\
\hline Age (years) & $43,3 \pm 11,0$ & $54,8 \pm 7,8$ & $<0,001$ \\
Male gender & $62,1(41)$ & $77,4(24)$ & 0,135 \\
Hypertension & $12,5(8)$ & $36,7(11)$ & 0,007 \\
Diabetes Mellitus & $4,7(3)$ & $6,7(30)$ & 0,635 \\
Dyslipidemia & $21,9(14)$ & $40,0(12)$ & 0,067 \\
Obesity & $12,5(8)$ & $16,1(5)$ & 0,752 \\
Early CAD Familial History & $10,9(7)$ & $13,3(4)$ & 0,74 \\
Smoking & $25,0(16)$ & $23,3(7)$ & 1,00 \\
\hline
\end{tabular}

Age expressed by mean and standard deviation

Male gender, hypertension, diabetes, dyslipidemia and obesity expressed by absolute frequencies (between parenthesis) and percentage

CAC: coronary artery calcium

With CAC: Agatston score $>0$

Without CAC: Agatston score $=0$

HIV+: human immunodeficiency viruses patients

CAD: coronary artery disease.

p: statistical significance (Exact Fisher test, qui² test and T Student test)

Source: Authors.

Table 1 shows CAC distribution among 97 HIV-infected patients. There was found 31.9\% of altered CAC (different from zero). Altered CAC patients are older than without calcification ones $(54.8 \pm 7.8$ years vs. $43.3 \pm 11.0$ years; $p<0.0001)$ as well as more prone to have hypertension (36.7 vs. 12.5 ; $\mathrm{p}=0.007)$. There were no differences for male gender, dyslipidemia and obesity. 


\subsection{Factors associated with $\mathrm{CAC}$ in $\mathrm{HIV}$-infected patients.}

Table 2. Unadjusted hazards ratios and $95 \%$ confidence intervals of factors associated with incident CAC (Agatston score $>0$ ) in HIV-infected patients.

\begin{tabular}{|c|c|c|c|}
\hline Variables & Hazard ratio & $95 \% \mathrm{CI}$ & $\mathbf{p}$ \\
\hline Age (years) & 1,13 & $1,07-1,20$ & $<0,0001$ \\
\hline Male gender & 2,09 & $0,79-5,56$ & 0,14 \\
\hline Hypertension & 4,05 & $1,42-11,60$ & 0,0009 \\
\hline Diabetes Mellitus & 1,45 & $0,23-9,20$ & 0,69 \\
\hline Dyslipidemia & 2,38 & $0,93-6,1$ & $\mathbf{0 , 0 7}$ \\
\hline Obesity & 1,35 & $0,40-4,52$ & 0,63 \\
\hline Early CAD Familial History & 1,25 & $0,34-4,60$ & 0,74 \\
\hline Smoking & 0,91 & $0,33-2,53$ & 0,86 \\
\hline Sedentarism & 0,98 & $0,42-2,40$ & 0,98 \\
\hline Protease Inhibitors use & 1,95 & $0,81-4,69$ & 0,14 \\
\hline
\end{tabular}

Unadjusted logistic regression; HR: hazard ratio

CAC (coronary artery calcium) presence defined as Agatston score $>0$ HIV+: human immunodeficiency viruses patients

CAD: coronary artery disease

p: statistical significance (Exact Fisher test, qui ${ }^{2}$ test and T Student test)

Source: Authors.

To describe factors associated with atherosclerosis (Agatston score $>0$ ) unadjusted hazards ratios (HR) model was used (Table 2). The unadjusted prevalence of CAC was associated with age $(\mathrm{HR}=1.13 ; 95 \% \mathrm{CI}=1.07-1.20$ and $\mathrm{p}<0.0001)$ and hypertension $(\mathrm{HR}=4.05 ; 95 \% \mathrm{CI}=1.42-11.60$ and $\mathrm{p}=0.0009)$.

To go far on addressing the question of which factors affect CAC incidence in HIV-infected patients, we constructed some multivariable adjusted models as shown in table 3. 
Table 3. Adjusted hazards ratios and $95 \%$ confidence intervals of factors associated with incident CAC (Agatston score $>0$ ) in HIV-infected patients.
Model 1
Model 2
Model 3
Model 4

\begin{tabular}{|c|c|c|c|c|c|c|c|c|c|}
\hline Variables & HR(95\%CI) & & $\mathbf{p}$ & HR(95\%CI) & $\mathbf{p}$ & HR(95\% CI) & $\mathbf{p}$ & HR(95\%CI) & $\mathbf{p}$ \\
\hline \multirow[t]{2}{*}{ Age (years) } & $1.13(1.06$ & - & $<0.000$ & $1.15(1.07-$ & $<0.000$ & $1,13(1.06-1.21)$ & $<0.001$ & & \\
\hline & 1.21) & & 5 & $1.23)$ & 1 & & & & \\
\hline Male gender & $\begin{array}{l}3.66(1.07 \\
12.60)\end{array}$ & - & 0.039 & $\begin{array}{l}2.95(0.93- \\
9.30)\end{array}$ & 0.066 & $\begin{array}{l}3,70(1.08- \\
12.80)\end{array}$ & 0.038 & $\begin{array}{l}3,43(1.04- \\
11.30)\end{array}$ & 0.042 \\
\hline Hypertension & $\begin{array}{l}3.27(0.80 \\
13.40)\end{array}$ & - & 0.098 & & & $2,51(0.65-9.70)$ & 0.18 & $\begin{array}{l}8,34(2.32- \\
29.90)\end{array}$ & 0.001 \\
\hline Protease Inhibitors & $\begin{array}{l}2.94(0.97 \\
8.90)\end{array}$ & - & 0.057 & $\begin{array}{l}2.46(0.86- \\
7.10)\end{array}$ & 0.095 & & & $2,96(1.09-8.07)$ & 0.034 \\
\hline
\end{tabular}

Adjusted logistic regression; HR: hazard ratio

CAC (coronary artery calcium) presence defined as Agatston score $>0$

Model 1 adjusted for age, male gender, hypertension and protease inhibitors use (PI)

Model 2 adjusted for model 1 covariates excluding hypertension

Model 3 adjusted for model 1 covariates excluding PI use

Model 4 adjusted for model 1 covariates excluding age

HIV+: human immunodeficiency viruses patients

p: statistical significance (Exact Fisher test, qui ${ }^{2}$ test and T Student test)

Souce: Authors.

The HR for CAC incidence among HIV+ adjusted for age, male gender, hypertension and use of PI (in Model 1) was $1.13(95 \% \mathrm{CI}=1.06-1.21$ and $\mathrm{p}<0.0005), 3.66(95 \% \mathrm{CI}=1.07-12.60$ and $\mathrm{p}=0.039), 3.27(95 \% \mathrm{CI}=0.80-13.40$ and $\mathrm{p}=0.098)$ and $2.94(95 \% \mathrm{CI}=0.97-8.90-1.21$ and $\mathrm{p}=0.057)$ respectively. When hypertension was excluded (Model 2) associated factor was only age $\mathrm{HR}=1.15(95 \% \mathrm{CI}=1.07-1.23$ and $\mathrm{p}<0.0001)$. HR for male gender was $2.95(95 \% \mathrm{CI}=0.93-9.30$ and $\mathrm{p}=0,066)$ and for PI use was $2.46(95 \% \mathrm{CI}=0.86-7.10$ and $\mathrm{p}=0.095)$. In Model 3, without PI, age $1.13(95 \% \mathrm{CI}=1.06-1.21$ and $\mathrm{p}<0.001)$ and male gender $3.70(95 \% \mathrm{CI}=1.08-12.80$ and $\mathrm{p}=0.038)$ were associated with $\mathrm{CAC}$ more than zero. There was no statistical significance for hypertension $2.51(95 \% \mathrm{CI}=0.65-9.70$ and $\mathrm{p}=0.18)$ in this model. Factors associated with an increased hazard of incident CAC included male gender $3.43(95 \% \mathrm{CI}=1.04-11.30$ and $\mathrm{p}=0.042)$, hypertension $8.34(95 \% \mathrm{CI}=2.32-29.90$ and $\mathrm{p}=0.001)$ and PI use $2.96(95 \% \mathrm{CI}=1.09-8.07$ and $\mathrm{p}=0.034)$ in Model 4.

Table 4. Age distribution in HIV-infected patients.

\begin{tabular}{ll}
\hline & Age (years) \\
\hline Median & 52 \\
$1^{\circ}$ quartile & 43 \\
$3^{\circ}$ quartile & 63 \\
\hline
\end{tabular}

HIV+: human immunodeficiency viruses patients. Source: Authors. 
Age distribution among our HIV-infected population is shown in Table 4. Note that it is a kind of young, with median of 52 years and interquartile range from 43 to 63 years. To address how that proportion of ages influences regression, we constructed a model including only patients older than 40 years (Table 5).

Table 5. Adjusted hazards ratios and $95 \%$ confidence intervals of factors associated with incident CAC (Agatston score $>0$ ) in HIV/AIDS patients $>40$ years old.

\begin{tabular}{lccc}
\hline Variables & Hazard ratio & $95 \% \mathrm{CI}$ & $\mathbf{p}$ \\
\hline Age (years) & 1,08 & $0,998-1,17$ & 0,0056 \\
Male gender & 3,61 & $1,06-12,30$ & 0,041 \\
Hypertension & 3,32 & $0,84-13,20$ & 0,088 \\
Protease Inhibitors & 3,38 & $1,10-10,40$ & 0,033 \\
\hline
\end{tabular}

Adjusted logistic regression; HR: hazard ratio

CAC (coronary artery calcium) presence defined as Agatston score $>0$

HIV+: human immunodeficiency viruses patients

CAD: coronary artery disease

p: statistical significance (Exact Fisher test, qui ${ }^{2}$ test and T Student test)

Source: Authors.

Increased likelihood of CAC incidence was strongly associated with age, male gender and PI use among HIV-infected patients.

\subsection{General differences between HIV-infected patients and control.}

Table 6. Comparison between HIV infected (HIV+) and HIV uninfected (HIV-) patients.

\begin{tabular}{lccc}
\hline & HIV+ $(\mathrm{n}=97)$ & HIV $-(\mathrm{n}=129)$ & p \\
\hline Age (mean) & $\mathbf{4 6 , 9 \pm 1 1 , 4}$ & $\mathbf{5 5 , 5} \pm 14,8$ & $<0,001$ \\
Male & $67,0(65)$ & $57,4(74)$ & 0,17 \\
Hypertension & $20,2(19)$ & $50,4(65)$ & $<0,001$ \\
Diabetes & $5,3(5)$ & $23,3(30)$ & $<0,001$ \\
Dyslipidemia & $27,7(26)$ & $34,9(45)$ & $\mathbf{0 , 3 1}$ \\
Obesity & $13,7(13)$ & $12,4(16)$ & 0,84
\end{tabular}

Age expressed by mean and standard deviation; male gender, hypertension, diabetes, dyslipidemia and obesity expressed by absolut frequences (between parentesis) and percentage; p: statistic significance (Exact Fisher test, qui ${ }^{2}$ test and T Student test); HIV+: human immunodeficiency viruses patients; HIV- : soronegative patients. Source: Authors. 
Comparison between HIV infected (HIV+) and HIV uninfected (HIV-) patients (control) is shown in table 6. We selected 129 seronegative to confront with our 97 HIV-infected individuals sample. Those findings reveal that HIV-infected patients are younger and less likely to have hypertension and diabetes than HIV uninfected ones. There are no differences in terms of male gender, dyslipidemia and obesity.

\subsection{Sample CACs distribution by HIV-infected status}

Table 7. CACs distribution among HIV infected patients (HIV+) and control (HIV-).

\begin{tabular}{llll}
\hline & HIV+ $(\mathbf{n}=97)$ & HIV $-(\mathbf{n}=129)$ & p \\
\hline CACs (Agatston) & $68,0(66)$ & $56,8(73)$ \\
1 a 10 & $8,2(8)$ & $8,5(11)$ & \\
11 a 100 & $15,5(15)$ & $15,5(19)$ & 0,21 \\
101 a 400 & $4,1(4)$ & $8,5(11)$ & \\
$>400$ & $4,1(4)$ & $10,9(14)$ \\
\hline
\end{tabular}

Agatston CACs (coronary calcium score) values expressed by absolut frequences (between parentesis) and percentage; p: statistic significance (Exact Fisher test, qui ${ }^{2}$ test and $\mathrm{T}$ Student test); HIV+: human immunodeficiency viruses patients; HIV- : soronegativos patients. Source: Authors.

Most patients in this sample have no coronary calcification (68\% in HIV/AIDS patients and 56.8\% in soronegative ones). Among HIV/AIDS patients 30.9\% presents altered CACs (more than zero) while is 42.3\% among control (Table 7), showing heterogeneous calcification levels. Importantly CACs reveal no difference between the two groups.

\section{Discussion}

Patients with HIV infection have a greater risk of developing CAD compared with no infected individuals, raising the need of search factors associated with it (Patel A et al, 2021). This report shows an expressive 32.9\% prevalence of CAC among HIV-infected patients, in according to previous studies with similar population (Grundy S et al, 2019). A study with 255 HIV-infected patients and serial cardiac CT scans over a 3-year follow-up confirmed that coronary atherosclerosis progression is accelerated in HIV-infected patients (Vilela F et al, 2011).

In this transversal study of $97 \mathrm{HIV}$-infected patients compared to control group (129 HIV-negative patients), people living with HIV are younger as less likely to have hypertension and diabetes than uninfected ones, even so reflecting a higher cluster of traditional CV risk factors, despite they show similarities in gender, dyslipidemia and obesity. Nevertheless, CACs reveal no difference between the two groups, suggesting that HIV+ patients presents some particular aspect leading them evolve like uninfected patients at higher risk. It is possible that such a behavior is due to HIV infection and its antiretroviral treatment (Freiberg M et al, 2013; Wang X et al, 2007; Worm S et al, 2010) Inflammation and immune activation are largely proven to be part of HIV infection, contributing as predictor of CAD (Kingsley L et al, 2015). A large cohort found a strong association of HIV with increased risk of myocardial infarction, independent of traditional risk factors (Lewden C et al, 2007; 
Vilela F et al, 2011). Previous studies suggests ART may cause dyslipidemia, hypertension and endothelial dysfunction, particularly with PI use, because of its recognized influence on lipid profile (elevated total cholesterol and triglyceride levels, and predispose to hypertension) in contrast with other antiretroviral drugs (Nadel J et al, 2017).

Stratifying individuals at risk of CV events is always challenging and it is not different in HIV-infected patients. Tools able to refine this search have been enrolled, like $\mathrm{C}$ reactive protein, carotid intimal thickness and ankle-brachial index. Among them, in a multivariate hazard analyses, CACs prove to be better, with a hazard ratio 2.69 (Ingle S et al, 2014). CACs has already proved its value to change risk stratum when confronted to Framingham risk score and other risk markers (Lo J et al, 2010), justifying its employment.

Our report also provides evidence that patients are older than without calcification ones and prone to have hypertension. Such information is important because of difficulty in estimate who is in major risk, emerging HIV-specific risk assessment tools. The Data Collection on Adverse Events of Anti-HIV Drugs (DAD) study was a prospective multinational cohort study that recruited $22625 \mathrm{HIV}$-infected patients sought to develop a model that predicted the risk of CAD. The model includes age, sex, systolic blood pressure and exposure to certain ART regimens. Kind of strategy was found to be more accurate in predicting the risk of CAD in the HIV-infected population (Nadel $\mathbf{J}$ et al, 2017). Nevertheless several samples studied before have stated age as a huge risk factor for CAC, as well as great influence of traditional cardiovascular risk factors (Erbel R et al, 2010; Lo J et al, 2010). Taken together these findings call attention to the importance for refine risk stratification among HIV-infected patients. Understanding that persons with HIV have accelerated atherosclerosis is important to provide appropriate care to a large and aging population with HIV.

We also found male gender as a factor for CAC related to HIV-infected patients. Many factors contribute to HIVassociated CAD, with chronic inflammation and immune activation leading (increased monocyte activation, inflammation, and hyperlipidemia present in chronic HIV infection take place). Moreover, people living with HIV have a higher prevalence of traditional cardiovascular risk factors than uninfected persons do. Men are at greater risk in almost the totality of studies (Lang S et al, 2015; Sinha A et al, 2019; Almeida-Brasil et al, 2019).

Antiretroviral therapies, although clearly necessary for HIV treatment and survival, control virus at the expense of metabolic changes. They have modified HIV infection course, allowing the infected population to age and be at risk of cardiovascular disease, especially CAD (Ingle S et al, 2014). It is of note that the role sample receives ART since current recommendations define initiation of early treatment in HIV-infected patients, before fall in CD4+ count. Indeed, by the year of 2015, the World Health Organization released a recommendation to start antiretroviral drugs in all HIV infected patients, regardless of CD4+ (Gilbert J et al, 2015; Lundgren J et al, 2015). Such a profile enhances inflammation, immune activation and endothelial dysfunction, important factors in HIV associated CAD (WHO, 2016; Lo J et al, 2009), mainly by the use of PI. Furthermore, antiretroviral regimen can be chosen in several ways, being suggested to use that one with more favorable lipid profile and few drugs interactions, taking into account patients features. Despite in general PI particularly cause harmful lipid profile changes, they are also excellent drugs to control HIV, and because of this, new generation of PI, with less adverse effects, have emerged (Lewden C et al, 2007; Ghislain M et al, 2015). The present study brings increased likelihood of CAC incidence in those patients and its strong association with PI use. Harmful side effects of ART had been described and include insulin resistance, dyslipidemia and endothelial dysfunction, especially PI. Fortunately, newer generation regimens have reduced cardiovascular toxicities (Kearns A et al, 2017; Gutierrez J et al, 2017; Vachiat A et al, 2017).

\section{Conclusion}

This study assessed patients with HIV infection from a developing country in order to find factors associated to CAC. Our data rises the hypothesis that increased likelihood of CAC incidence was strongly associated with age, male gender and PI 
use. Evidences pointed out a greater risk of CV events among HIV-infected patients and that HIV itself, as well as ART, are possible causes for this pattern. CACs figure as an excellent risk predictor and can be useful for stratify CAD asymptomatic HIV- infected individuals. Future researches may focus on models to better stratify HIV patients in order to improve efforts toward risk reduction in this population.

\section{References}

Agatston, A. S., Janowitz, W. R., Hildner, F. J., Zusmer, N. R., Viamonte, M., \& Detrano, R. (1990). Quantification of coronary artery calcium using ultrafast computed tomography. Journal of the American College of Cardiology, 15(4), 827-832.

Almeida-Brasil, C. C., Nascimento, E. D., Silveira, M. R., Bonolo, P. D. F., \& Ceccato, M. D. G. B. (2019). New patient-reported outcome measure to assess perceived barriers to antiretroviral therapy adherence: the PEDIA scale. Cadernos de saude publica, 35.

Chandra, D., Gupta, A., Fitzpatrick, M., Haberlen, S. A., Neupane, M., Leader, J. K., Kingsley, L. A., Kleerup, E., Budoff, M. J., Witt, M., Sciurba, F. C., Post, W. S., \& Morris, A. (2019). Lung Function, Coronary Artery Disease, and Mortality in HIV. Annals of the American Thoracic Society, 16 (6), 687-697.

Erbel, R., Möhlenkamp, S., Moebus, S., Schmermund, A., Lehmann, N., Stang, A., \& Heinz Nixdorf Recall Study Investigative Group. (2010). Coronary risk stratification, discrimination, and reclassification improvement based on quantification of subclinical coronary atherosclerosis: the Heinz Nixdorf Recall study. Journal of the American College of Cardiology, 56(17), 1397-1406.

Freiberg, M. S., Chang, C. C. H., Kuller, L. H., Skanderson, M., Lowy, E., Kraemer, K. L., \& Justice, A. C. (2013). HIV infection and the risk of acute myocardial infarction. JAMA internal medicine, 173(8), 614-622.

Freiberg, M. S., Chang, C. H., Kuller, L. H., Goetz, M. B., Leaf, D., \& Oursler, K. A. HIV infection and the risk of acute myocardial infarction. JAMA Intern Med [Internet]. 2013; 173 (8): 614-22.

Friis-Møller, N., Ryom, L., Smith, C., Weber, R., Reiss, P., Dabis, F., \& Law, M. (2016). An updated prediction model of the global risk of cardiovascular disease in HIV-positive persons: The Data-collection on Adverse Effects of Anti-HIV Drugs (D: A: D) study. European journal of preventive cardiology, 23(2), 214-223.

Ghislain, M., Bastard, J. P., Meyer, L., Capeau, J., Fellahi, S., Gérard, L., \& ANRS-COPANA Cohort Study Group. (2015). Late antiretroviral therapy (ART) initiation is associated with long-term persistence of systemic inflammation and metabolic abnormalities. PLoS One, $10(12)$, e0144317.

Gilbert, J. M., Fitch, K. V., \& Grinspoon, S. K. (2015). HIV-related cardiovascular disease, statins, and the REPRIEVE trial. Topics in antiviral medicine, 23(4), 146.

Grundy, S. M., Stone, N. J., Bailey, A. L., Beam, C., Birtcher, K. K., Blumenthal, R. S., \& Yeboah, J. (2019). 2018 AHA/ACC/AACVPR/AAPA/ABC/ACPM/ADA/AGS/APhA/ASPC/NLA/PCNA guideline on the management of blood cholesterol: a report of the American College of Cardiology/American Heart Association Task Force on Clinical Practice Guidelines. Journal of the American College of Cardiology, 73(24), e285e350.

Gutierrez, J., Albuquerque, A. L. A., \& Falzon, L. (2017). HIV infection as vascular risk: a systematic review of the literature and meta-analysis. PloS one, 12(5), e0176686.

Ingle, S. M., May, M. T., Gill, M. J., Mugavero, M. J., Lewden, C., Abgrall, S., \& Antiretroviral Therapy Cohort Collaboration. (2014). Impact of risk factors for specific causes of death in the first and subsequent years of antiretroviral therapy among HIV-infected patients. Clinical Infectious Diseases, 59(2), 287297.

Julius, H., Basu, D., Ricci, E., Wing, J., Kusari Basu, J., Pocaterra, D., \& Bonfanti, P. (2011). The burden of metabolic diseases amongst HIV positive patients on HAART attending The Johannesburg Hospital. Current HIV research, 9(4), 247-252.

Kearns, A., Gordon, J., Burdo, T. H., \& Qin, X. (2017). HIV-1-associated atherosclerosis: unraveling the missing link. Journal of the American College of Cardiology, 69(25), 3084-3098.

Kingsley, L. A., Jennifer, D. E. A. L., Jacobson, L., Budoff, M., Mallory, W. I. T. T., Palella, F., \& Calhoun, B. (2015). Incidence and progression of coronary artery calcium (CAC) in HIV-infected and HIV-uninfected men. AIDS (London, England), 29(18), 2427.

Lang, S., Boccara, F., Mary-Krause, M., \& Cohen, A. (2015). Epidemiology of coronary heart disease in HIV-infected versus uninfected individuals in developed countries. Archives of cardiovascular diseases, 108(3), 206-215.

Lewden, C., Chêne, G., Morlat, P., Raffi, F., Dupon, M., Dellamonica, P., \& Leport, C. (2007). HIV-infected adults with a CD4 cell count greater than 500 cells/mm3 on long-term combination antiretroviral therapy reach same mortality rates as the general population. JAIDS Journal of Acquired Immune Deficiency Syndromes, 46(1), 72-77.

Lo, J., Abbara, S., Shturman, L., Soni, A., Wei, J., Rocha-Filho, J. A., \& Grinspoon, S. K. (2010). Increased prevalence of subclinical coronary atherosclerosis detected by coronary computed tomography angiography in HIV-infected men. AIDS (London, England), $24(2), 243$.

Lo, J., Looby, S. E. D., Wei, J., Adler, G. K., \& Grinspoon, S. K. (2009). Increased aldosterone among HIV-infected women with visceral fat accumulation. AIDS (London, England), 23(17), 2366.

Lundgren, J. D., Babiker, A. G., Gordin, F., Emery, S., Grund, B., Sharma, S., \& Neaton, J. D. (2015). Initiation of antiretroviral therapy in early asymptomatic HIV infection. The New England journal of medicine, 373(9), 795-807. 
Research, Society and Development, v. 10, n. 12, e442101220484, 2021

(CC BY 4.0) | ISSN 2525-3409 | DOI: http://dx.doi.org/10.33448/rsd-v10i12.20484

Mooney, S., Tracy, R., Osler, T., \& Grace, C. (2015). Elevated biomarkers of inflammation and coagulation in patients with HIV are associated with higher Framingham and VACS risk index scores. PloS one, 10(12), e0144312.

Nadel, J., \& Holloway, C. J. (2017). Screening and risk assessment for coronary artery disease in HIV infection: an unmet need. HIV medicine, 18(4), 292299.

Patel, A. A., \& Budoff, M. J. (2021). Coronary artery disease in patients with HIV infection: an update. American Journal of Cardiovascular Drugs, 21(4), 411-417

Sara, L, Szarf, G, Tachibana, A, Shiozaki, A. A, Villa, A. V., Oliveira, A. C., et al. Sociedade Brasileira de Cardiologia. II Diretriz de Ressonância Magnética e Tomografia Computadorizada Cardiovascular da Sociedade Brasileira de Cardiologia e do Colégio Brasileiro de Radiologia. Arq Bras Cardiol 2014; 103(6Supl.3): 1-86

Senoner, T., Barbieri, F., Adukauskaite, A., Sarcletti, M., Plank, F., Beyer, C., \& Feuchtner, G. M. (2019). Coronary atherosclerosis characteristics in HIVinfected patients on long-term antiretroviral therapy: insights from coronary computed tomography-angiography. Aids, 33(12), 1853-1862.

Sinha, A., \& Feinstein, M. J. (2019). Coronary artery disease manifestations in HIV: what, how, and why. Canadian Journal of Cardiology, 35(3), $270-279$.

Triant, V. A., Lee, H., Hadigan, C., \& Grinspoon, S. K. (2007). Increased acute myocardial infarction rates and cardiovascular risk factors among patients with human immunodeficiency virus disease. The Journal of Clinical Endocrinology \& Metabolism, 92(7), $2506-2512$.

Vachiat, A., McCutcheon, K., Tsabedze, N., Zachariah, D., \& Manga, P. (2017). HIV and ischemic heart disease. Journal of the American College of Cardiology, 69(1), 73-82.

Vilela, F. D., Lorenzo, A. R. D., Tura, B. R., Ferraiuoli, G. I., Hadlich, M., Barros, M. V. D. L., \& Meirelles, V. (2011). Risk of coronary artery disease in individuals infected with human immunodeficiency virus. Brazilian Journal of Infectious Diseases, 15, 521-527.

Wang, X., Chai, H., Yao, Q., \& Chen, C. (2007). Molecular mechanisms of HIV protease inhibitor-induced endothelial dysfunction. JAIDS Journal of Acquired Immune Deficiency Syndromes, 44(5), 493-499.

World Health Organization. (2016). Consolidated guidelines on HIV prevention, diagnosis, treatment and care for key populations. World Health Organization.

World Health Organization. (2016). Global health sector strategy on viral hepatitis 2016-2021. Towards ending viral hepatitis (No. WHO/HIV/2016.06). World Health Organization.

Worm, S. W., Sabin, C., Weber, R., Reiss, P., El-Sadr, W., Dabis, F., \& Lundgren, J. (2010). Risk of myocardial infarction in patients with HIV infection exposed to specific individual antiretroviral drugs from the 3 major drug classes: the data collection on adverse events of anti-HIV drugs (D: A: D) study. The Journal of infectious diseases, 201(3), 318-330. 